\title{
Design of the Otjikoto Gold Mill, Namibia
}

\author{
John Rajala ${ }^{1}$ \\ Received: 25 May 2020 / Accepted: 13 October 2020 / Published online: 30 October 2020 \\ (C) The Author(s) 2020
}

\begin{abstract}
The Otjikoto Gold Mine in the Republic of Namibia is located approximately 300 kilometers north of the capital city of Windhoek. The project features surface mining with a modern gravity/carbon-in-pulp mill for ore treatment and recovery of gold. Initial mill design capacity was 2.5 million tonne per annum but then expanded after 9 months of operation to 3.1 million tonne per annum. The technical steps to establish the Otjikoto mill design from process selection in the due diligence stage, through flowsheet development in the feasibility study followed by detailed engineering design are reviewed in this paper along with mill performance during start-up and in 2019.
\end{abstract}

Keywords Otjikoto $\cdot$ Gold $\cdot$ Mill $\cdot$ Design $\cdot$ Flowsheet $\cdot$ Testing

\section{Introduction}

The Otjikoto Gold Mine is in the north-central section of the Republic of Namibia approximately 300 kilometers north of the capital city Windhoek. B2Gold Namibia, operator of the Otjikoto Mine, is $90 \%$ owned by B2Gold Corp. of Vancouver, B.C., Canada and $10 \%$ by EVI Mining of Namibia. B2Gold Corp. finalized acquisition of the Otjikoto Project in December 2011 following a 3-month due diligence study. A feasibility study and NI 43-101 report [1] were completed in 2012 and early 2013, respectively, then detailed design engineering started in January 2013 as well as earthworks site construction. Mill commissioning began in November 2014, with the first gold pour the following month on December 11. Commercial production was declared on February 28, 2015.

The Otjikoto deposit, discovered in 1999, is classified as an orogenic-style gold deposit with a sheeted sulfide/quartz/carbonate vein system. Native gold occurs within the vein system as particles typically varying from $5-400 \mu \mathrm{m}$, with significant presence of coarse gold. Sulfide mineralization includes pyrrhotite and pyrite. The Otjikoto deposit feasibility study probable mineral reserve was 29.4 million tonnes at a grade of 1.42

Permission granted to submit for publication from B2Gold Corp. Disclosure Committee.

John Rajala

jrajala@b2gold.com

1 B2Gold Corp., Vancouver, BC, Canada g/t Au. Since initial mine development, an adjacent deposit known as Wolfshag has also been developed.

Mine operations consist of surface mining and a milling facility. The gold mill uses a modern gravity recovery/carbon-in-pulp (CIP) process to extract and recover gold from run-of-mine (ROM) ore. Initial mill design was for a throughput of 2.5 million tonnes per annum (Mtpa) but was then expanded to 3.1 Mtpa after 9 months of operation.

The technical steps and stages of development in the design of the Otjikoto mill as well as the process performance in the start-up phase and for 2019 are discussed.

\section{Process Selection}

\subsection{Due Diligence Study}

During the due diligence stage, a scoping level process tradeoff study was completed to select between a gravity recovery/ flotation/concentrate leach option and a gravity recovery/ whole ore leach option. At the beginning of due diligence, the plan had been to use the gravity/flotation/concentrate leach process; however, gold recoveries from various tests on the three major types (oxide, transition and sulfide) were erratic and relatively low for the oxide samples. Thus, additional test work was quickly completed to produce new metallurgical data for both process options to use in the trade-off study.

The process trade-off study determined that the capital cost of the gravity recovery/whole ore leach process would be $\$ 41.8$ million US higher and the operating cost would be 
$\$ 0.78 /$ tonne higher than the corresponding costs for the gravity/flotation/concentrate leach option. The single largest difference in the capital cost between the two process options was an additional $\$ 16.8$ million US for the large fully lined gravity/whole ore leach tailings storage facility (TSF) compared to a small lined TSF for concentrate leach residue and an unlined impoundment for the flotation tailings. However, the combined gold recovery for all ore types was $11.1 \%$ higher for the gravity/whole ore leach process, and therefore the incremental Net Present Value (NPV) was $\$ 63.7$ million US higher compared to the alternative option. A gold price of $\$ 1,250$ US per troy ounce and $10 \%$ discount rate were used in the economic analysis.

Table 1 presents an economic comparison of the in situ resource revenue for the two process options. The bottomline economic benefit of the whole ore leach process compared to flotation/concentrate leach was an additional \$5.22/ tonne in revenue due to the significantly higher gold recovery achieved by the whole ore process. Therefore, the gravity/ leach process was selected for the feasibility stage.

\section{Flowsheet Development}

\subsection{Feasibility Study}

The primary objective of the feasibility metallurgical test program was to develop an optimized flowsheet and provide the necessary data for design criteria for the gravity/whole ore leach process. The initial steps in the metallurgical program were the selection of test samples and establishing the scope of the test work.

\subsubsection{Test Samples}

The test samples selected were based on the three major ore types in the Otjikoto deposit which are oxide, transition, and sulfide. For each ore type there were three master composites prepared for the process development metallurgical and comminution test work, and then additional comminution and metallurgical samples were selected to evaluate variability response. The oxide, transition, and sulfide metallurgical master composites were prepared using 33, 42, and 80 drill core intervals, respectively, and were weighted to the occurrence in the Otjikoto deposit. There were an additional 46 metallurgical (recovery) samples and 17 comminution samples prepared for the variability test work. PQ and HQ core were used for the preparation of all samples, and NQ core was also used for preparation of deeper metallurgical variability samples.

\subsubsection{Metallurgical Test Work Scope}

The metallurgical test work scope included: (1) chemical and mineralogical analysis, (2) comminution (crushing/grinding) tests, (3) gravity separation, (4) cyanide leach amenability and optimization, (5) thickener and rheology testing, (6) cyanide destruction, (7) carbon adsorption, (8) ore flow testing, and (9) tailings characterization. The following provides a brief description of testing and key results.

Chemical and Mineralogical Analysis Comprehensive chemical analysis was performed on each metallurgical master composite and variability sample by various methods including fire assay, Leco, X-ray fluorescence (XRF) and ICP. Table 2 presents the results of the chemical analyses of various elements and species of interest in gold ores. There were no deleterious elements or species of metallurgical concern other than the relatively high sulfide content in the transition and sulfide ore composites.

Mineralogical analyses were performed on each metallurgical composite using quantitative evaluation of materials by scanning electron microscopy (QEMSCAN), X-ray diffraction (XRD), and optical microscopy and scanning electron microscopy (SEM). The major findings of the mineralogical examination included the identification of plagioclase $\left[(\mathrm{NaSi}, \mathrm{CaAl}) \mathrm{AlSi}_{2} \mathrm{O}_{8}\right]$ as the dominant gangue mineral in all master composites and with quartz $\left(\mathrm{SiO}_{2}\right)$ and calcite $\left(\mathrm{CaCO}_{3}\right)$ present in moderate concentrations in the oxide composite. The second highest concentration of gangue minerals in transition and sulfide ore composites were quartz and ankerite

Table 1 In situ revenue per tonne of resource

\begin{tabular}{llll}
\hline & Whole ore leach & $\begin{array}{l}\text { Flotation/ } \\
\text { leach }\end{array}$ & Difference \\
\hline OPEX [USD/t] & & 4.28 & 0.78 \\
CAPEX [USD/t] & 5.06 & 2.67 & 1.64 \\
Overall gold recovery [\%] & 4.31 & 84.5 & 11.1 \\
Gold revenue [USD/t] & 95.6 & 58.51 & 7.64 \\
Overall economic benefit [USD/t] & 66.15 & 51.56 & 5.22 \\
\hline
\end{tabular}


Table 2 Chemical analysis of master metallurgical composites

Metallurgical master composite Assays

\begin{tabular}{lllllllllllllllll} 
& $\mathrm{Au}$ & $\mathrm{Ag}$ & $\mathrm{Stot}$ & $\mathrm{S}^{2-}$ & $\mathrm{SO} 4$ & $\mathrm{C}(\mathrm{tot})$ & $\mathrm{C}(\mathrm{g})$ & $\mathrm{TOC}$ & $\mathrm{CO} 3$ & $\mathrm{Cu}$ \\
$(\%)$ & $(\%)$ & $\begin{array}{l}\mathrm{Zn} \\
(\%)\end{array}$ & $\begin{array}{l}\mathrm{Fe} \\
(\%)\end{array}$ & $\begin{array}{l}\mathrm{As} \\
(\mathrm{g} / \mathrm{t})\end{array}$ & $\begin{array}{l}\mathrm{Sb} \\
(\%)\end{array}$ & $\begin{array}{l}\mathrm{Hg} \\
\mathrm{g} / \mathrm{t}\end{array}$ \\
\hline Oxide & 1.64 & $<0.5$ & 0.04 & $<0.05$ & $<0.1$ & 2.35 & 0.04 & $<0.05$ & 10.4 & 0.016 & 0.002 & 8.14 & $<30$ & $<0.002$ & $<0.3$ \\
Transition & 1.70 & $<0.5$ & 2.98 & 2.77 & $<0.1$ & 2.41 & 0.05 & 0.22 & 10.8 & 0.015 & 0.002 & 10.3 & $<30$ & $<0.002$ & $<0.3$ \\
Sulfide & 1.75 & $<0.5$ & 4.05 & 3.86 & $<0.1$ & 2.08 & 0.03 & 0.12 & 9.34 & 0.012 & 0.001 & 10.1 & $<30$ & $<0.002$ & $<0.3$ \\
\hline
\end{tabular}

$\left[\mathrm{CaFe}\left(\mathrm{CO}_{3}\right)_{2}\right]$, with pyrrhotite present in moderate concentrations in the sulfide composite and pyrite in minor concentrations in the transition composite. The XRD results were all confirmed by QEMSCAN and the concentration of pyrrhotite in the sulfide ore composite was determined to be $10.8 \%$ and the pyrite concentration in the transition ore composite was determined at 5.6\%. A gold deportment study of all three metallurgical composites identified the gold particle sizes ranging from less than a few microns up to 436 microns. The dominant gold occurrence was in the native form as determined by SEM with energy dispersive spectroscopy (EDS). Figure 1 shows a gold particle from the sulfide ore composite that measures over 200 microns in length. The occurrence of coarse native gold particles pointed toward the potential of recovery by gravity separation.

Comminution Testing The comminution tests on the oxide, transition, and sulfide master composites and the 17 variability samples included the full suite of Bond tests (low energy impact, rod and ball mill grindability, abrasion index) and SMC tests. In addition, JK drop weight tests were performed on the master composites to enable accurate calibration of the SMC results. Table 3 presents the crushing and grinding results used for the simulation work in the grinding circuit design. The 85 th percentile of hardness from the comminution results on

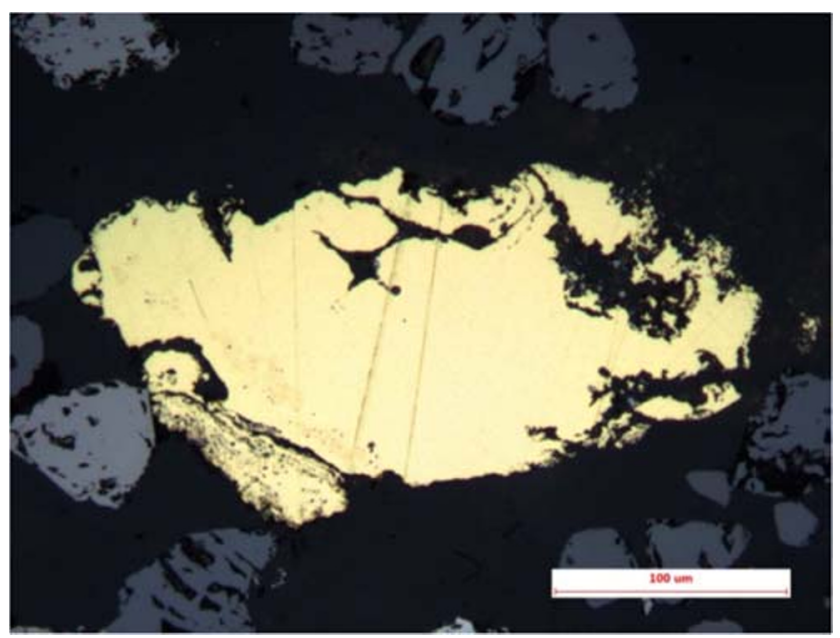

Fig. 1 Gold particle in the sulfide ore composite the sulfide variability samples were used for the grinding circuit design because sulfide is the dominant ore type and the hardest in the Otjikoto deposit. Of the 17 variability samples evaluated, nine were from the sulfide domain. The test program was formulated to collect all necessary data for design of a SAG/ball mill/pebble crushing (SABC) circuit.

Gravity Separation Extended gravity recoverable gold (EGRG) tests were completed using a 3-inch lab Knelson concentrator (KC-MD3) on the three metallurgical master composites [2]. The results are shown in Table 4. Gravity recoverable gold values were very high for all composites varying from 76.5 for oxide ore to $88.1 \%$ for transition ore. The GRG results were then used in a gravity modeling study with centrifugal concentrators.

Cyanidation Test Work The feasibility cyanidation test work focused on optimization of leach conditions for treatment of the gravity tails product from the three metallurgical composites [3]. A range of parameters were assessed including grind (leach feed) size, pretreatment time, lead nitrate addition, leach residence time, cyanide concentration, and dissolved oxygen level. Grind size was the initial variable evaluated and the leach test results showed that a $\mathrm{P}_{80}$ size of 74 microns was optimum. Three $\mathrm{P}_{80}$ grind sizes were evaluated including 150,100 , and 74 microns on each of the three master metallurgical composites. The grind size selection was based on optimizing the economic benefit taking into consideration incremental differences between gold extraction, grinding power consumption, ball mill grinding media/liner consumption, sodium cyanide consumption, and cyanide destruction reagent consumption for the three grind sizes assessed.

Table 3 Comminution dataset for grinding simulation work

\begin{tabular}{|c|c|c|c|c|c|c|}
\hline \multirow{2}{*}{$\begin{array}{l}\text { Dataset } \\
\text { for simulations }\end{array}$} & \multirow{2}{*}{$\begin{array}{l}\text { Relative } \\
\text { density }\end{array}$} & \multicolumn{2}{|c|}{ JK parameter } & \multicolumn{3}{|c|}{ Work index $(\mathrm{kWh} / \mathrm{t})$} \\
\hline & & $\mathrm{A} \times \mathrm{b}$ & $\mathrm{t}_{\mathrm{a}}$ & CWI & RWI & BWI \\
\hline Oxide-85th perc. & 2.56 & 90.6 & 0.91 & 16.9 & 9.1 & 7.2 \\
\hline Transition-85th perc. & 2.58 & 43.6 & 0.44 & 16.9 & 11.7 & 8.5 \\
\hline Sulfide- 85 th perc. & 2.77 & 42.3 & 0.39 & 16.9 & 12.3 & 9.3 \\
\hline
\end{tabular}


Table 4 GRG results for oxide, transition, and sulfide ore types

\begin{tabular}{lll}
\hline Ore type & Grade $(\mathrm{g} / \mathrm{t})$ & GRG $(\%)$ \\
\hline Oxide & 1.75 & 76.5 \\
Transition & 2.44 & 88.1 \\
Sulfide & 1.77 & 80.9 \\
\hline
\end{tabular}

The effect of lead nitrate addition with a 7-hour pretreatment, $\mathrm{pH} 10.5,500 \mathrm{ppm} \mathrm{NaCN}$ concentration, dissolved oxygen (DO) concentration $>5 \mathrm{ppm}$, and $45 \%$ solids leach density on gold recovery from the sulfide ore composite is presented in Fig. 2. The selection of the $45 \%$ solids leach density, a pulp density within the typical range of $40-50 \%$ solids for agitated whole ore gold leaching, was fixed throughout the test work. The results indicated there was no additional benefit in overall gold extraction with lead nitrate addition above 100 $\mathrm{g} / \mathrm{t}$. The leach rate curve showed that gold recovery (extraction) stabilized at 48 hours. The final optimized conditions for the sulfide ore composite that were used in the leach circuit design were a residence time of 48 hours, 7-hour pretreatment with $100 \mathrm{~g} / \mathrm{t}$ lead nitrate, $300 \mathrm{ppm} \mathrm{NaCN}$ concentration, DO concentration $>5 \mathrm{ppm}$ (by air addition), and $45 \%$ solids leach density. A higher DO concentration of $16 \mathrm{ppm}$ improved gold leach kinetics slightly in the laboratory test program; however, it did not increase overall gold recovery and had marginally higher cyanide consumption. No laboratory oxygen demand testing was conducted, and therefore plant-scale oxygen requirements for air addition were based on an engineering database for sulfide ore leach circuits. Design air additions were $0.24 \mathrm{Nm} / \mathrm{h} / \mathrm{m}^{3}$ for pretreatment and $0.20 \mathrm{Nm}^{3} / \mathrm{h} / \mathrm{m}^{3}$ for leaching.

Thickener and Rheology Testing Thickener and rheology test work included flocculant screening, sedimentation testing for optimum settling flux and thickener sizing criteria, and thickened mud rheology to determine required rake torque and predict underflow product manageability to provide the design

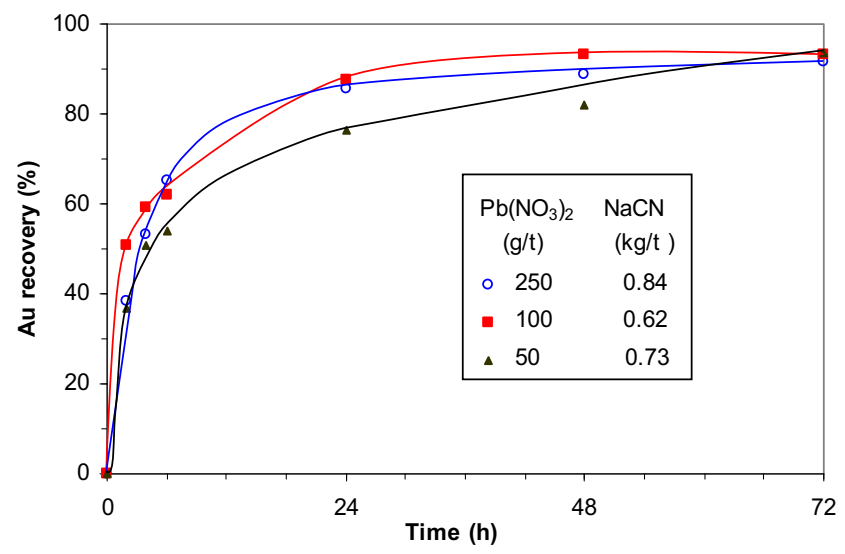

Fig. 2 Effect of lead nitrate addition and leach time on gold recovery from sulfide ore (2) basis for the pre-leach and tailings thickeners. The samples evaluated were gravity tails and cyanide destruction test products from the three metallurgical composites. The apparatus used for the sedimentation work was a continuous fill deep tube test and rheology was examined using a Haake VT550 viscometer fitted with a custom vane.

Key results from the thickener and rheology test program included (1) the selection of an anionic polyacrylamide flocculant with a high molecular weight and medium charge density produced the best settling rates and overflow clarity with effective flocculant dosages of $30-40 \mathrm{~g} / \mathrm{t}$ for oxide ore and 10 $20 \mathrm{~g} / \mathrm{t}$ for both transition and sulfide ore, (2) unit area requirements of $0.043 \mathrm{~m}^{2} / \mathrm{tpd}$ for oxide ore and $0.034 \mathrm{~m}^{2} /$ tpd for transition and sulfide ore, and (3) underflow pulp densities of $45-55 \%$ solids for the pre-leach thickener and $60-75 \%$ solids for the tailings thickener for the three composites tested.

Cyanide Destruction Cyanide destruction (CND) testing was performed using the $\mathrm{SO}_{2} /$ Air process. The work program included batch and continuous tests on the three metallurgical composites. Primary objectives of the CND test work were: (1) produce an effluent with $<10$ ppm CNwad concentration, (2) determine copper sulfate, lime and $\mathrm{SO}_{2}$ consumptions, and (3) establish optimum lab residence time.

Results from the CND tests on the three composites indicated the target effluent of $<10 \mathrm{ppm}$ CNwad was achievable with a feed loading of 200 ppm CNwad at $45 \%$ solids using $4 \mathrm{~g} \mathrm{SO}_{2} / \mathrm{g} \mathrm{CNwad}$. Copper catalyst (as copper sulfate pentahydrate) concentration required was $10 \mathrm{ppm}$ and lime consumption was $3 \mathrm{~g} / \mathrm{g}$ CNwad. The optimum lab residence time was $60 \mathrm{~min}$. All lab test data was then used in the cyanide destruction process study.

Carbon Adsorption Carbon adsorption test work was conducted to produce the required data for CIP modeling. Kinetic loading curves were generated from activated carbon adsorption tests on the three metallurgical composites. The test results produced the kinetic constant $(\mathrm{k})$ and the equilibrium constant (K) for the three different ore types. Values for $\mathrm{kK}$ of 50 or less are indicative of poor CIP performance, whereas values of 100 or more are indicative of good performance. The $\mathrm{kK}$ values obtained in the test work for adsorption from $45 \%$ solids slurry were 122 for oxide ore, 172 for transition ore and 126 for sulfide ore, which were favorable for CIP performance. The relatively slow leaching rate of the sulfide ore gravity tails ruled out the possibility of using carbon-inleach (CIL). The use of CIL was also unnecessary as it was determined from early tests that none of the three ore types exhibited preg robbing characteristics.

Ore Flow Testing Ore flow testing was performed to provide the key results for the design of the stockpile reclaim system. Tests were conducted under various conditions and moisture 
contents to determine the materials flow characteristics for the three metallurgical composites. All composites demonstrated cohesive strength, especially the oxide ore sample which had the highest clay content (as montmorillonite), resulting in the recommendation of mass flow hoppers in the stockpile reclaim system and tent sections between feeders to create intersecting flow channels.

Tailings Characterization Tailings characterization included geochemical, acid rock drainage (ARD), contaminant release, and geotechnical tests for the Otjikoto tailings storage facility (TSF) design.

Geochemical tests performed on the cyanide destruction residues from the three metallurgical composites included: borate fusion X-ray fluorescence (XRF) whole rock analyses, inductively coupled plasma-optical emission spectroscopy/ mass spectroscopy (ICP-OES/MS), strong acid digest elemental analyses, toxicity characteristic leaching procedure (TCLP) extractions, shake flask extraction (SFE) testing, analysis of the decanted CND residue solutions, modified acid/base accounting (ABA), net acid generation (NAG) testing, and humidity cell testing.

Geotechnical testing completed on the three composites were: particle size distribution (PSD) by sieve and hydrometer, Atterberg limits, standard proctor, standard and drained settling tests, evaporation (air drying) tests, Rowe cell consolidation tests, hydraulic conductivity tests, and consolidated undrained $(\mathrm{CU})$ triaxial tests.

The suite of geochemical and geotechnical tests provided a comprehensive database for the TSF design. ASTM procedures were used in the tailings test work where applicable.

\subsection{Process Studies}

Several process studies were completed to develop the design basis and equipment sizing for various mill circuits. The more critical studies are presented here.

\subsubsection{Grinding Circuit Modeling and Simulation}

JKSimMet and Bond's third theory of comminution were used to model and simulate two Otjikoto grinding circuit alternatives. The circuits were SAG/ball mill (SAB) and SAG/ ball mill/pebble crushing (SABC). The 85 th percentile of hardness from the comminution test results presented in Table 3 were used in the modeling and simulation studies. Baseline simulations were run evaluating $24 \mathrm{ft}$ and $26 \mathrm{ft}$ diameter SAG mills with and without pebble crushing, $10 \%$ and $12 \%$ ball charges, $25 \%$ total charge levels, and the 85 th percentile sulfide ore results. The modeling and simulation results showed that a $24 \mathrm{ft}$ diameter $\mathrm{x} 14.5 \mathrm{ft}$ EGL SAG mill was not only effective in SAB configuration for the initial $2.5 \mathrm{Mtpa}$ design throughput but could also treat the anticipated expansion throughput of 3.1 Mtpa with the addition of a pebble crusher. The $17 \mathrm{ft}$ diameter $\mathrm{x} 28 \mathrm{ft}$ ball mill simulated was able to handle both initial design and expansion throughputs. Power requirements were determined for mill drive sizing at the initial and expansion throughputs. Simulations on each of the variability samples demonstrated the range of ore characteristics could be handled at the anticipated throughputs and design $\mathrm{P}_{80}$ grind size 74 microns.

\subsubsection{Gravity Recovery Modeling}

Gravity recovery modeling was completed using the GRG test results in Table 4. Due to the very high GRG content and coarse gold in all three major types, the circuit modeling was based on an aggressive treatment of the entire ball mill discharge assuming 300\% circulating load. The modeling results with four Knelson centrifugal concentrators are presented below in Table 5.

The gravity modeling results showed the four QS48 machines would handle the full ball mill circulating load even at the expanded throughput of 3.1 Mtpa with gravity gold recoveries ranging from $64.8 \%$ for oxide ore to $80.1 \%$ for transition ore. The sulfide ore gravity gold recovery of $71.9 \%$ was used for design. The concentrate production from the modeling also provided the data for sizing an intensive leach circuit for treatment of the gravity concentrate.

\subsubsection{CIP Modeling}

Semi-empirical models developed by Mintek [4-7] were used to model the CIP process using the gold kinetic and equilibrium carbon adsorption results and assumed operating conditions of $45 \%$ solids pulp density, carbon concentrations of 15 and $25 \mathrm{~g} / \mathrm{L}$, and eight stages of adsorption with 0.8 and 0.9 hours residence time per stage. The modeling results indicated that only six stages of adsorption with 0.9 hours residence time per stage and $15 \mathrm{~g} / \mathrm{L}$ carbon concentration could produce barren solutions with $<0.01 \mathrm{mg} / \mathrm{L}$ Au while treating the sulfide ore type; therefore, these results were used as the design basis for the Otjikoto CIP circuit.

Table 5 Gravity modeling results for 3 Otjikoto ore types

\begin{tabular}{|c|c|c|c|c|c|}
\hline \multirow[t]{3}{*}{ Ore type } & \multirow[t]{3}{*}{ Gravity equipment } & \multicolumn{4}{|c|}{ Gravity in ball mill discharge } \\
\hline & & \multicolumn{2}{|c|}{ Gravity recovery } & \multicolumn{2}{|c|}{ Concentrate data } \\
\hline & & $(\% \mathrm{Au})$ & (\% GRG) & $\mathrm{kg} /$ day & $\mathrm{g} /$ tonne \\
\hline Oxide & 4-QS48 & 64.8 & 90.4 & 6,192 & 1,169 \\
\hline Transition & 4-QS48 & 80.1 & 91.6 & 6,192 & 2,303 \\
\hline Sulfide & 4-QS48 & 71.9 & 89.3 & 6,192 & 1,500 \\
\hline
\end{tabular}




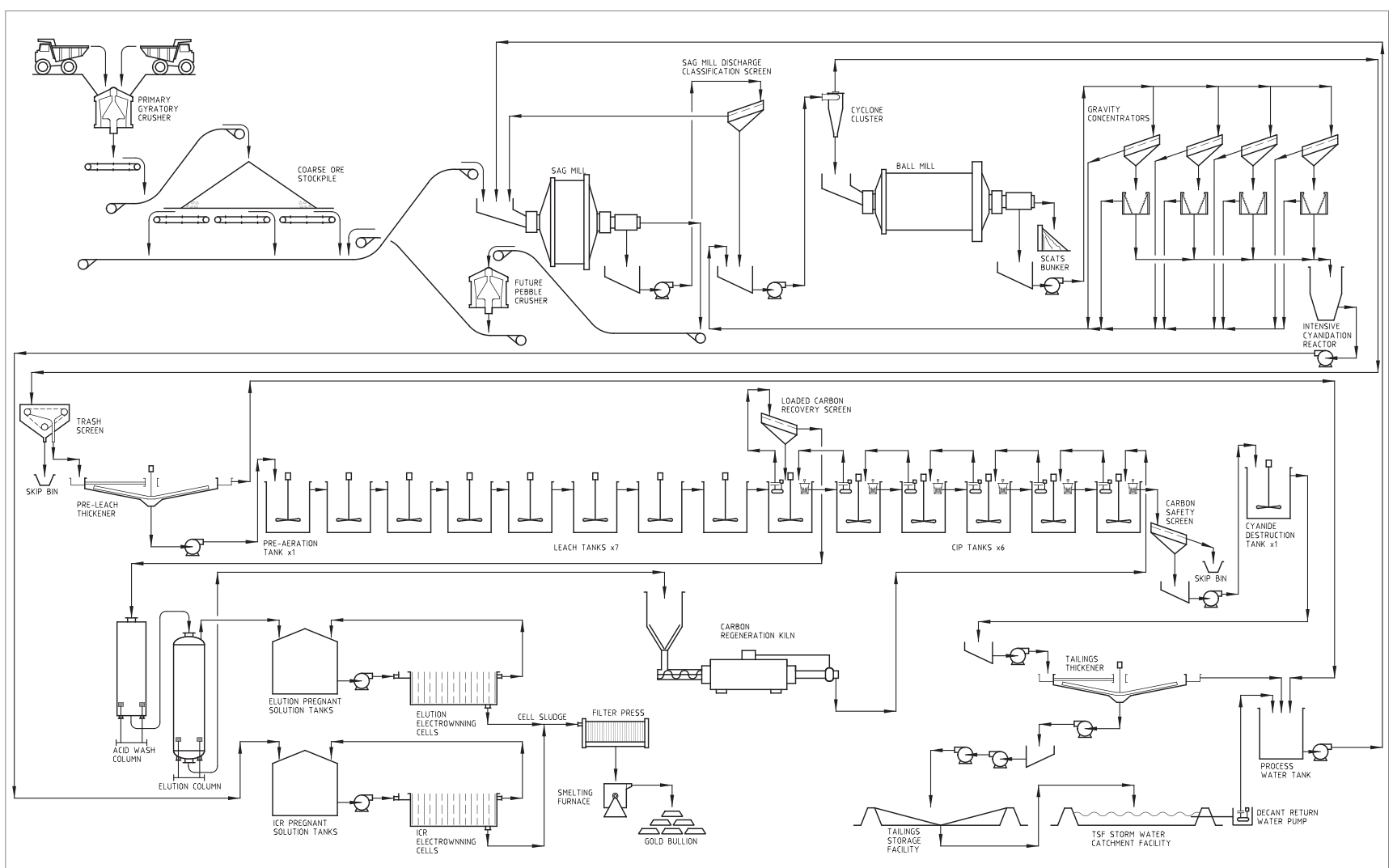

Fig. 3 Otjikoto mill flowsheet

\subsubsection{Cyanide Destruction}

The cyanide destruction results were used to develop the design basis for the plant circuit and size all equipment including the reactor, mixer, and reagent systems. The additional cyanidation leach optimization test work indicated significantly lower cyanide concentration of 300 ppm would be optimum for sulfide ore; therefore, the plant design was based on a CND feed loading of $160 \mathrm{ppm}$ CNwad. Final reactor design residence time was 60 minutes with a pulp density of $42 \%$ solids and $\mathrm{SO}_{2}$ and lime consumptions of $5.0 \mathrm{~g} / \mathrm{g} \mathrm{CNwad}$ and $4.0 \mathrm{~g} / \mathrm{g} \mathrm{CNwad}$, respectively, to allow for potentially higher $\mathrm{CNwad}$ feed loadings. The design $\mathrm{Cu}$ concentration for the process catalyst was a concentration of $50 \mathrm{ppm}$. The CND circuit design was based on the use of sodium metabisulfite as the $\mathrm{SO}_{2}$ source, copper sulfate pentahydrate as the source of copper, and hydrated lime for the lime source.

\subsubsection{Tailings Study}

A tailings study was conducted to determine the optimum facility design using all the characterization test work as the materials engineering basis for the design. Because the topography at the Otjikoto site is relatively flat and the entire area is situated over a large aquifer, a lined ring dike impoundment with upstream construction of the tailings embankment was selected. A tailings cyclone underflow product is used for the embankment construction. The facility maximizes the recovery of mill effluent from the tailings through a decant tower system. This was an important consideration in the high evaporation climate at the site location. The TSF was designed as a zero-discharge impoundment.

\section{Process Design}

The critical documents to fully develop the process design include the flowsheet, design criteria, mass balance, and mechanical equipment list. The documents for the Otjikoto mill detailed engineering design are reviewed next. This information was then used in the mill 3-D model.

\subsection{Flowsheet and Description}

The Otjikoto mill flowsheet developed from the metallurgical test program and process studies is presented in Fig. 3. The flowsheet includes a primary gyratory crusher, crushed ore stockpile, and an SABC grinding circuit with a ball mill in closed circuit with cyclones to achieve the final product size. A Knelson concentrator gravity recovery circuit treats the entire ball mill discharge for coarse, free gold recovery. The Knelson concentrate is processed in an intensive leach reactor (ILR). ILR 
leach solution is treated by direct electrowinning. The cyclone overflow stream flows by gravity to a linear trash screen ahead of a pre-leach thickener. The pre-leach thickener underflow is pumped to the leach circuit that includes pretreatment. The preleach thickener overflow solution reports to the process water tank for use as make-up water. Pretreatment is performed with air and lime addition, and then further air is added to the leach tanks to maintain adequate dissolved oxygen concentration. Sodium cyanide is added to leach for gold extraction. A CIP circuit recovers dissolved gold onto activated carbon. A split AARL elution circuit is used to strip gold from loaded carbon for processing through electrowinning. Gold bars are produced at site from smelting the electrowinning sludge in an induction furnace. The $\mathrm{SO}_{2} /$ air cyanide destruction reduces the WAD cyanide level in the tailings stream to an environmentally acceptable level. The tailings stream is thickened to recover water before being pumped to the tailings storage facility.

\subsection{Mass Balance}

Comprehensive mass balances for ore, water, and reagent flows in all process circuits were developed for the 2.5 and 3.1 Mtpa throughputs. The mass balance data along with the metallurgical data were used for equipment and piping sizing and selection.

\subsection{Design Criteria}

Table 6 presents the key design criteria used for the engineering/design of the Otjikoto mill. To expand from 2.5 to 3.1 Mtpa throughput, a 25\% design factor was used. The sulfide ore type, which is the most dominant and metallurgical challenging in the Otjikoto deposit, was used as the design basis for the metallurgical processes. The oxide ore type, which had the most difficult materials handling characteristics, was used for the crushed ore stockpile reclaim system design.

Table 6 Key Otjikoto mill design criteria

Mill design criteria

\begin{tabular}{ll}
\hline Throughput & $2.5 \mathrm{Mtpa}$, expansion to 3.1 Mtpa \\
\hline Availability & $92 \%$ \\
Gravity gold recovery & $71 \%$ (sulfide ore modeling) \\
Leach gold extraction & $89.8 \%$ (sulfide ore leach optimization) \\
Overall gold recovery & $95.6 \%$ (1.5\% scale-up discount) \\
Grind size & $80 \%$ passing 74 microns \\
Leach/CIP residence time & 48 hours (leach), 6 hours (CIP) \\
Carbon elution & 5 tonne/day \\
Cyanide destruction & $\mathrm{SO}_{2} /$ Air \\
\hline
\end{tabular}

\subsection{Mechanical Equipment and Systems}

The major mechanical equipment and systems selected for the Otjikoto mill design are presented in Table 7 . The SAG mill selection was the same size as used in the JKSimMet modeling study; however, the ball mill was a slightly smaller diameter $(0.15$ meter $)$ due to the manufacturer's standard sizing but was an insignificant factor in grinding capacity. All equipment and unit operations selected were tried and proven in the gold industry and therefore provided confidence in the expected performance. The gravity equipment and circuit were unconventional in the design to handle $100 \%$ of the ball mill circulating load to provide a very aggressive gravity recovery effort due to the ore's high GRG content. The major equipment for the mill expansion from 2.5 to 3.1 Mtpa are also listed in Table 7 and include the pebble crusher and two new leach tanks. Other significant expansion equipment included additional cyclones, leach blower, tailings pumps, and new SAG mill grates to increase the pebble production to feed the pebble crushing circuit.

The power generation and process control systems were also included in Table 7 because of the important contributions to the mill operation. Power generation is by heavy fuel oil (HFO) gensets (with diesel back-up) due to grid capacity and reliability issues at the time of design and has proven to be an effective power supply. A 7 MW (dc) solar facility was added in 2018 to reduce power generation costs. The distributed control system provides fully integrated process control of all circuits in the mill operation.

\subsection{3-D Mill Model}

A software modeling package from Navisworks was used to develop a 3-D model of the Otjikoto mill. As mentioned above, the mill model was based on the flowsheet, design criteria, mass balance, and equipment selection. The model development initially proceeds with mechanical layout, followed by structural, concrete, electrical, piping and instrumentation design. Maintenance and operations access as well as constructability were all very important considerations in the model development. Upon completion of fully detailed design of each circuit and system, the model was then used to produce the 2-D construction drawings. Figure 4 presents a plan view of the overall mill layout from primary crushing through tailings thickening and ancillary facilities located near and around the mill. The open-air construction and in-line placement of circuits with wide corridors addressed all accessibility and construction objectives. 
Table 7 Major mill mechanical equipment list and systems

\begin{tabular}{ll}
\hline Equipment/system & Size \\
\hline Primary crusher & $1,067 \mathrm{~mm}$ x 1,651 mm Gyratory - 375 kW \\
Crushed ore stockpile & 6,500 tonne live capacity \\
SAG mill & 7.3 meter dia. x 4.4 meter EGL - $4,000 \mathrm{~kW}$ \\
Ball mill & 5.0 meter dia. x 8.5 meter - $4,000 \mathrm{~kW}$ \\
Pebble crusher & HP 300/Shorthead Cone Crusher \\
Gravity circuit & $(4)$ QS48 Knelson Concentrators \\
Intensive leach & Acacia CS8000 Reactor - 6.6 tonne \\
Pre-leach thickener & 20 meter dia. X 2.7 meter side wall \\
Pretreatment (2 Tk)/leach circuit (8 Tk) & 15.8 meter dia. x 18 meter high \\
CIP circuit (6 Tk) & 9.3 meter dia. x 9.8 meter high \\
Elution & Split AARL - 5 tonne elution vessel \\
Electowinning cells & $(4) 2.8$ cubic meter \\
Smelting & Induction furnace - $150 \mathrm{~kW}$ \\
SO2/Air cyanide destruction & Reactor, 10.8 meter dia. x 11.2 meter high \\
Tailings thickener & 20 meter dia. x 5 meter side wall \\
Tailings storage facility & Lined ring dike, upstream construction \\
Power generation & 24 MW - HFO and diesel, 7 MW (dc) solar \\
Process control & Emerson DeltaV Distributed Control System \\
\hline
\end{tabular}

Fig. 4 Plan view of Otjikoto mill layout

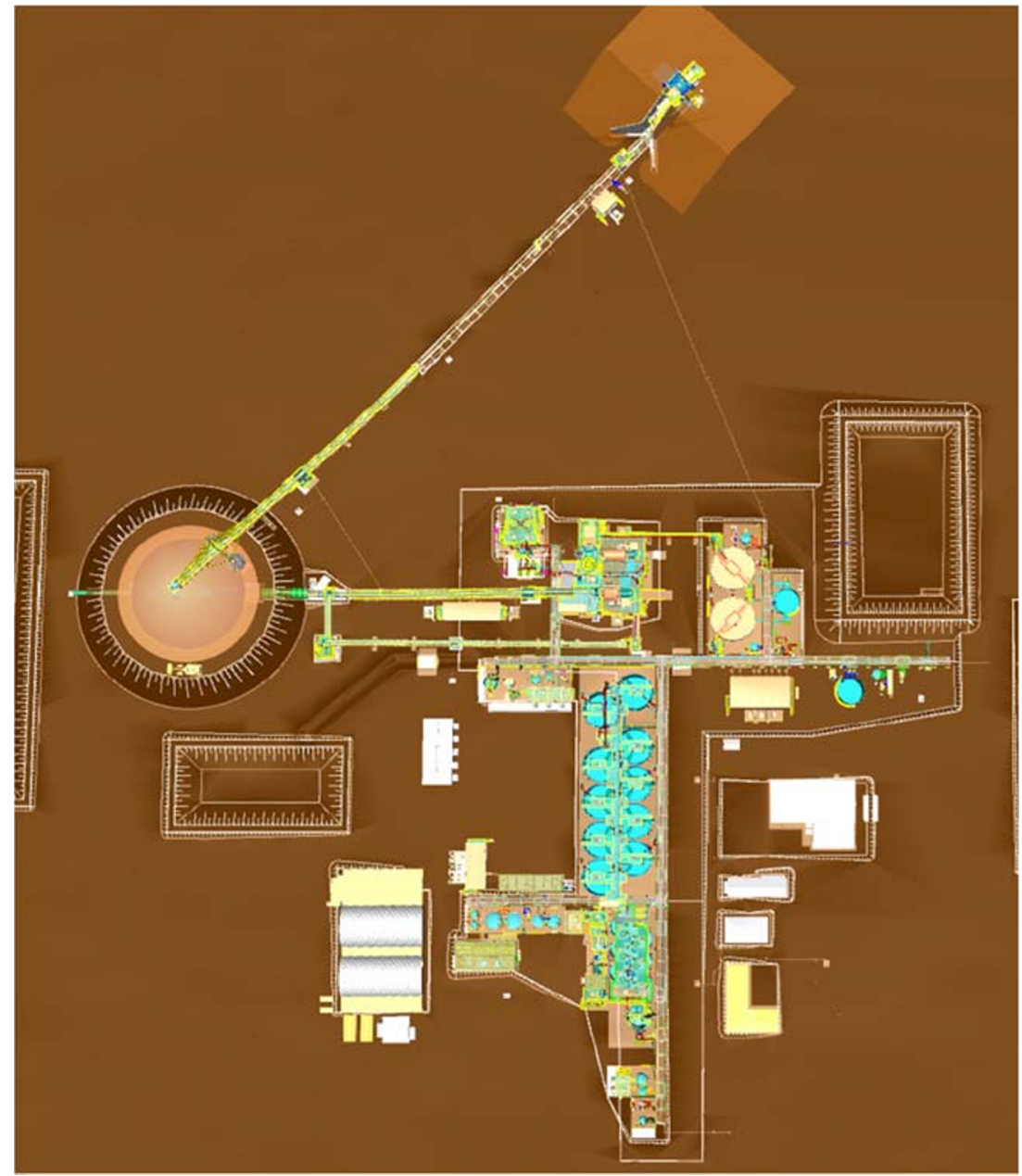


Fig. 5 Otjikoto mill monthly throughput profile from start-up in December 2014 to June 2015

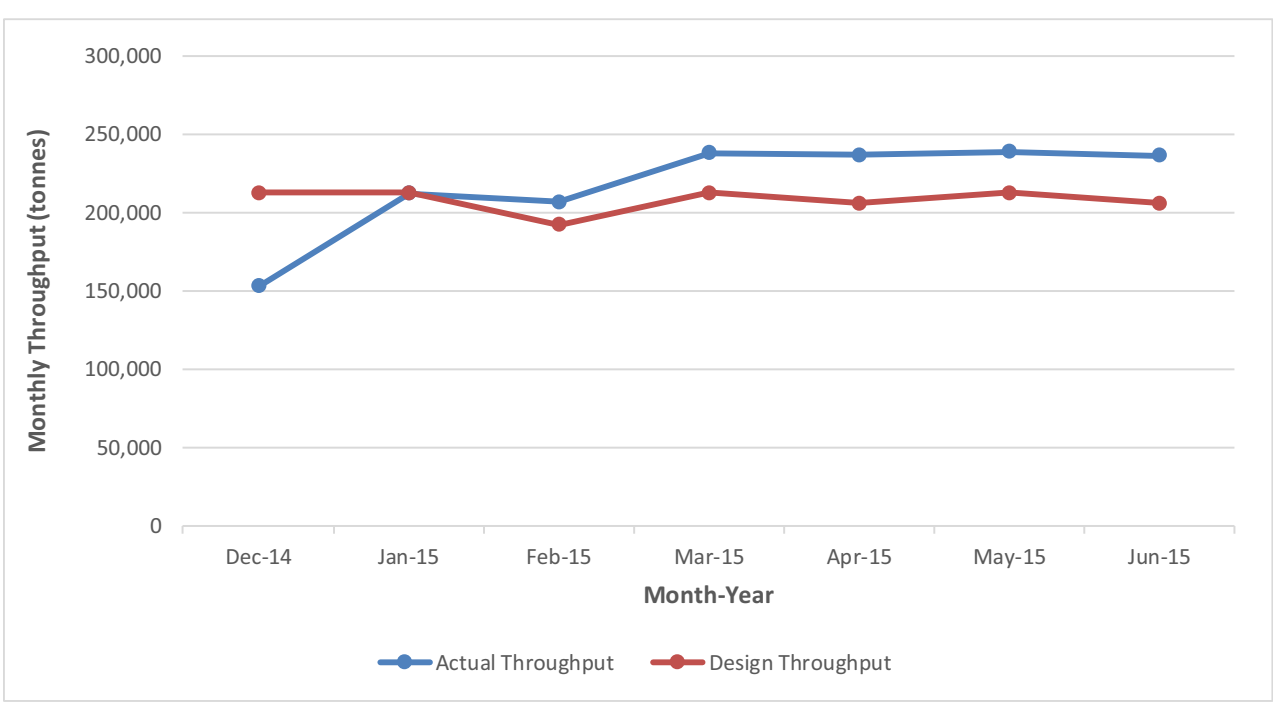

\section{Mill Start-up}

The throughput and gold recovery profiles from the December 2014 start-up through the first half of 2015 are presented in Figs. 5 and 6 , respectively. The monthly throughput profile presents a comparison of actual tonnes processed with design throughput. Mill throughput in December 2014 was well below design due to various start-up issues but quickly increased and then exceeded design throughput from February 2015 onward.

The comparison of actual with design gold recovery in Fig. 6 shows lower recovery over the initial two months of operation, but then recovery significantly exceeding design from February through June 2015. June gold recovery was $98.9 \%$. Gold recovery was lower than design in December 2014 due to the frequent mill stoppages from commissioning issues that caused numerous process upsets and a coarser than design grind size $\mathrm{P}_{80}$ of 82 microns.
The most serious commissioning issue was a malfunction of the SAG mill variable speed drive. Mill availability was $72.2 \%$ in the initial month of operation. Gold recovery improved from $93.5 \%$ in December to $94.3 \%$ in January 2015 with a corresponding increase in mill availability of $89.6 \%$ and steadier process operation.

It is noted that the design recovery had a discount factor of $1.5 \%$ applied to the lab recovery for scale-up to plant to account for soluble gold and gold in fine carbon losses; however, mill recovery still exceeded design without the discount over the February-June period.

\section{Process Performance}

The 2019 process performance is summarized in the bullets below. A comparison of various 2019 key performance

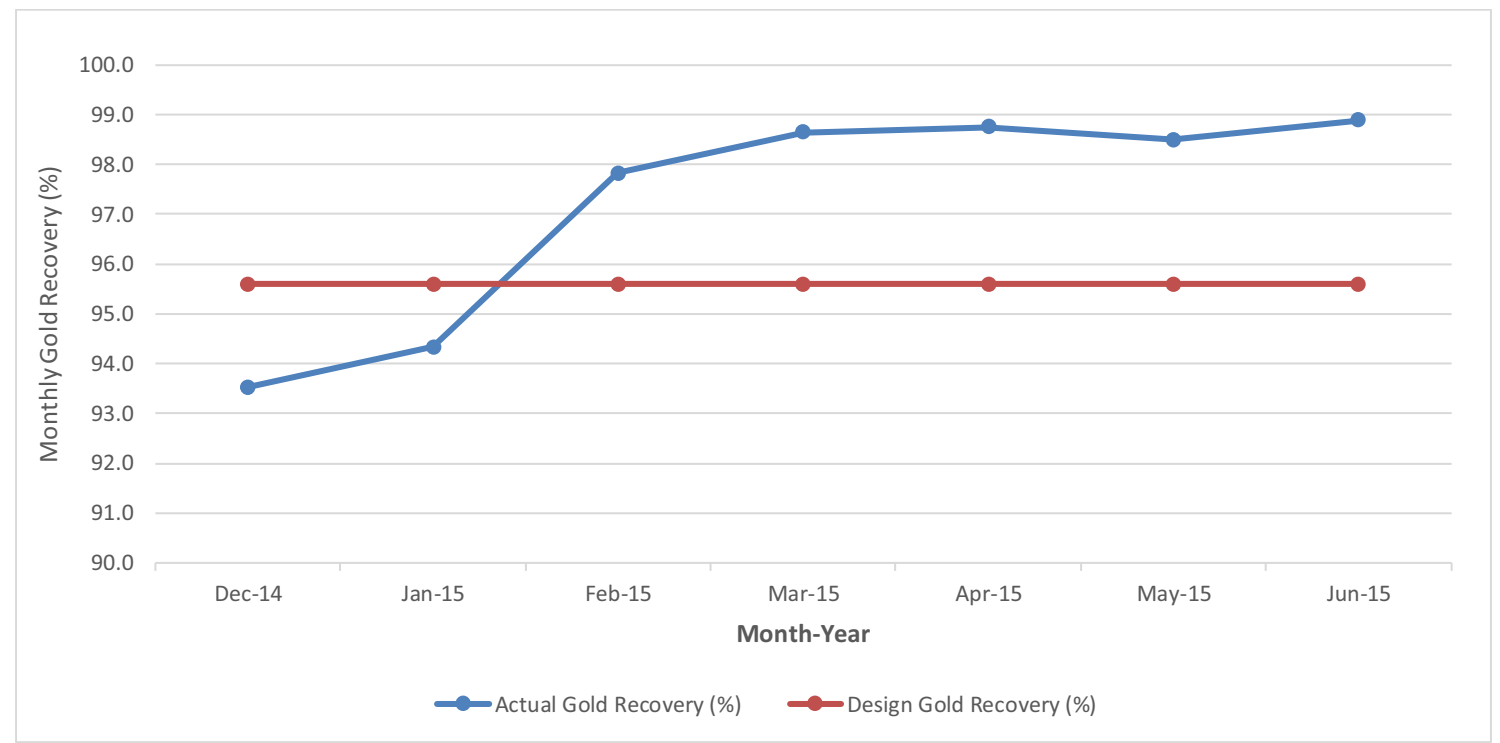

Fig. 6 Otjikoto mill gold recovery profile from start-up in December 2014 to June 2015 
indicators (KPIs) is made with design values. The 2019 mill results exceeded design for all KPI comparisons except for gravity gold recovery. Gravity gold recovery was less than design primarily due to lower average availability of the Knelson concentrators compared to modeling, lower average gold extraction in the Acacia intensive leach circuit (98\% in model vs $91 \%$ actual), possible variability in GRG content, and cyclone classification variation from modeling. Despite lower gravity gold recovery, overall gold recovery was high at 98.7\%. Gold leach kinetics in the 2019 operation were typically much faster than the lab leach kinetics, which is the primary reason for the higher than design overall gold recovery. It is also possible overall gold recovery exceeded design in part because of preferential finer grinding of gold locked in sulfide minerals due to the cyclone classification compared to the lab batch grinding/leach tests, which is sometimes observed in other similar sulfide gold ore processes. The 2019 mill feed blend was $88 \%$ Otjikoto pit ore and $12 \%$ Wolfshag pit ore. Five years into the operation from start-up, mill performance is robust.

- Mill throughput: 3.4 Mt vs design 3.1Mt

- Feed grade: $1.6 \mathrm{~g} / \mathrm{t} \mathrm{Au}$

- Gravity gold recovery: $64.1 \%$ vs $71 \%$

- Leach extraction: $96.4 \%$ vs design $89.8 \%$

- Overall gold recovery: $98.7 \%$ vs design of $95.6 \%$

- Gold production: $178 \mathrm{~K} \mathrm{oz}$

- Availability: $92.9 \%$ vs design of $92.0 \%$

- Process operating costs: $\$ 11.78 /$ tonne, the major cost center was grinding at $\$ 3.80 /$ tonne

- Average grind $\mathrm{P}_{80}$ was 75 microns vs design 74 microns

- Sodium cyanide consumption of $314 \mathrm{~g} / \mathrm{t}$ vs design $660 \mathrm{~g} / \mathrm{t}$

- Average soluble gold CIP tails solution of $0.005 \mathrm{~g} / \mathrm{t}$ vs design $0.01 \mathrm{~g} / \mathrm{t}$

- Total process power consumption of $28.0 \mathrm{kWh} / \mathrm{t}$

\section{Summary}

The gravity/whole ore leach process option demonstrated significantly stronger economic potential in the due diligence stage compared to a gravity/flotation/concentrate leach option because of higher gold recoveries from the three major Otjikoto ore types. The feasibility metallurgical test program and process studies produced the comprehensive results and data to feed into the final flowsheet development, design criteria, mass balance, and equipment selection in the detailed process design. The 3 -D mill model became the cornerstone of the design phase leading to construction and eventual start-up and operation. The Otjikoto mill start-up in terms of throughput and gold recovery showed a very quick ramp-up with both parameters exceeding design after only 2 months of operation.
Robust process performance continued into 2019 with KPIs exceeding design values in almost every aspect of mill operation. The Otjikoto mill gold recovery is exceptionally high, exceeding $98 \%$ every year following start-up, especially considering the low-grade nature of the deposit.

Acknowledgements The author would like to thank senior management at B2Gold Corp. for permission to publish this paper. Special thanks to Bill Lytle, Senior Vice President of Operations, for his review and support of the paper. I would also like to thank Tom Carter, B2Gold EngineeringConstruction Manager, and the engineering staff at LycopodiumBrisbane for their excellent work on the Otjikoto mill detailed engineering design. Finally, I express my gratitude to the entire commissioning team led by Noel Avenido (B2Gold) and Sandy Hunter (Lycopodium) for their efforts and a job well done to complete a very successful start-up.

\section{Compliance with Ethical Standards}

Conflict of Interest The author states there is no conflict of interest.

Open Access This article is licensed under a Creative Commons Attribution 4.0 International License, which permits use, sharing, adaptation, distribution and reproduction in any medium or format, as long as you give appropriate credit to the original author(s) and the source, provide a link to the Creative Commons licence, and indicate if changes were made. The images or other third party material in this article are included in the article's Creative Commons licence, unless indicated otherwise in a credit line to the material. If material is not included in the article's Creative Commons licence and your intended use is not permitted by statutory regulation or exceeds the permitted use, you will need to obtain permission directly from the copyright holder. To view a copy of this licence, visit http://creativecommons.org/licenses/by/4.0/.

\section{References}

1. Lytle B et al (2013) Otjikoto gold project NI 43-101 report - feasibility study. B2Gold Corp

2. Fullam $\mathrm{M}$ et al (2018) The Otjikoto gravity circuit: test work, design, commissioning and operation. In: Canadian Mineral Processors Conference. Ottawa, Canada

3. Deschênes G et al (2017) Otjikoto mill leach operation in 2015-16. Conference of Metallurgists, Vancouver, Canada

4. Fleming CA, Nicol MJ, Nicol DI (1980) The optimization of carbonin-pulp adsorption circuit based on the kinetics of extraction of aurocyanide by activated carbon. Presented at Mintek meeting 'Ion Exchange and Solvent Extraction in Mineral Processing'. Randburg, Mintek.

5. Fleming CA, Nicol MJ (1984) The adsorption of gold cyanide onto activated carbon: 3 factors influencing the rate of loading and equilibrium capacity. J South African Inst Min Metall 84(4):85-93

6. Nicol MJ, Fleming CA, Cromberge G (1984a) The adsorption of gold cyanide onto activated carbon 1: The kinetics adsorption from pulps. J South African Inst Min Metall 84(2):50-54

7. Nicol MJ, Fleming CA, Cromberge G (1984b) The adsorption of gold cyanide onto activated carbon 2: application of the kinetic model to multistage adsorption circuits. J South African Inst Min Metall 84(3):70-78

Publisher's Note Springer Nature remains neutral with regard to jurisdictional claims in published maps and institutional affiliations. 